\title{
The investigation of the effects of Ramadan fasting on the mood state of healthy volunteer persons
}

\author{
Ramazan orucunun sağlıklı gönüllü kişilerin ruh hali üzerine etkisinin araştırılması
}

\section{Ozgur Erdem ${ }^{\text {a }}$}

${ }^{a}$ Lice Halis Toprak Vakfi Devlet Hastanesi, Diyarbakir, Turkey

\begin{abstract}
Introduction: The present study was carried out to investigate the effect of Ramadan fasting on human psychology among healthy volunteer people.

Methods: In this cross-sectional type study, the universe of the research is composed of healthy volunteer people who registered at the Kayapinar Peyas family health centre in Diyarbakır and declared they planned to fast at the month of Ramadan in 2017. A questionnaire form including a sociodemographic questionnaire and Turkish version of the Depression Anxiety Stress Scale (DASS-42) was formed. The online questionnaire technique was used to obtain the data via e-mail and smartphone. The study was conducted during the summer of 2017 . The survey conducted to the same healthy volunteer group one weak before Ramadan (May 22-26) and at the end of Ramadan (June 21-25). SPSS 21.0 statistical package was used in the data analysis. The statistical analyses were considered significant if $\mathrm{p}<0.05$.

Results: 73 healthy volunteer subjects with no known health problems and who were not in the risk groups in terms of mental and physical health were included in the statistical evaluation. According to the DASS score, when the pre-Ramadan scores of the samples were compared to the postRamadan scores; depression $(p=0.001)$, anxiety $(p=0.01)$ and stress $(p=0.002)$ scores were found to be lower at the end of Ramadan. When compared to the pre-Ramadan scores of the samples and the post-Ramadan scores; anxiety $(\mathrm{p}<0.05)$ prevalence was found to be lower at the end of Ramadan.

Conclusion: The results of the current study demonstrated that fasting in the month of Ramadan have been effective in diminishing stress, anxiety, and depression levels.

Keywords: Depression, Anxiety, Stress, Ramadan fasting, Psychology

$\ddot{O Z Z}$

Giriş: Bu çalışma Ramazan orucunun insan psikolojisi üzerindeki etkilerini araştırmak amacıyla gönüllü kişiler arasında yapılmıştır.

Yöntem: Kesitsel tipteki bu çalışmada, araştırmanın evrenini Diyarbakır Kayapınar Peyas aile sağlı̆̆1 merkezinde kayıtlı olan ve 2017 yılı Ramazan ayında oruç tutmayı planladığını beyan eden sağlıklı gönüllüler oluşturdu. Sosyodemografik verileri ve depresyon anksiyete stres skalasının (DASS-42) Tükçe versiyonunu içeren bir anket formu hazırlandı. Verilerin elde edilmesinde e-mail ve akıllı telefon aracılığ ile online anket tekniği kullanıldı. Anket 2017 yılı yazında Ramazan ayından bir hafta önce (22-26 Mayıs) ve Ramazanın en son haftasında (21-25 Haziran) aynı sağlıklı gönüllü gruba uygulandı. Verilerin analizinde SPSS 21,0 istatistiksel paket program kullanıldı. p<0,05 istatistiksel olarak anlamlı kabul edildi.

Bulgular: Bilinen herhangi bir sağlık problemi olmayan, ruh ve beden sağlığı açısından risk grubunda olmayan 73 sağlıklı ve gönüllü birey istatistiksel değerlendirmeye dahil edildi. DASS puanlarına göre depresyon, anksiyete ve stres düzeyi; Ramazan orucu öncesi ve Ramazan orucunun sonunda alınan toplam puanlar karşılaştırıldığında depresyon $(\mathrm{p}=0,001)$, anksiyete $(\mathrm{p}=0,01)$ ve stres $(\mathrm{p}=0,002)$ puanları Ramazan orucunun sonunda, Ramazan orucu öncesine göre düşük olarak bulundu. DAS skalasına göre Ramazanın sonunda anksiyete $(p<0,05)$ sıklığı Ramazan öncesine göre düşük bulundu.

Sonuç: Mevcut çalışma sonuçları, Ramazan ayında oruç tutmanın, stres, kaygı ve depresyon düzeylerini azaltmada etkili olduğunu göstermiştir. Anahtar Kelimeler: Depresyon, Anksiyete, Stres. Ramazan orucu, Psikoloji
\end{abstract}

Submission: Feb 24, 2018

Acceptance: Jan 18, 2018

E-mail: dr.oerdem@hotmail.com

Correspondence: Ozgur Erdem, Lice Halis Toprak Vakfi Devlet Hastanesi 21700 Lice-Diyarbakir/TURKEY

$\underline{\text { www.fppc.com.tr }}$ 


\section{Introduction}

The role of spirituality and religion in health and disease has been considered in recent years and some believe that spirituality is part of the biological-psychological-social model. There are evidences that show strong religious beliefs; spiritual longing, prayer, and worship have positive effects on a person's physical and mental health (1). In this regard, the efforts have recently been increased to elucidate the connection between religion and mental health (2). Many studies have demonstrated positive effects of religion on mental health while some have reported negative effects $(3,4)$. Moreover, religious components such as trust in God, reading or listening to Quran, participation in repetitive rituals like prayers and fasting during Ramadan have been revealed to have positive relationship with decreased rates of depression, anxiety, and stress (5-7). The fast of Ramadan is one of the five pillars of Islam; it is also one of the greatest of the marks and observances of Islam. There are many purposes and instances of wisdom in the fast of Ramadan with aspects to God Almighty's dominicality, man's social and personal life, and the training of his instinctual soul, and his gratitude for divine bounties (8).

Healthy and sedentary individuals have been frequently investigated through Ramadan fasting. Although fasting in the month of Ramadan is influential on physical and mental health based on religion of Islam (2) and several studies have described the effect of fasting on physical health (9-12), few investigations have addressed to the relationship between fasting and mental health (13-15). Studies examining the association of fasting and mood can be divided into two groups: the first group features experimental studies, while the other groups of studies are observational studies on the effects of Ramadan on mood, i.e. a partial fasting for one month per year. Recent clinical observations demonstrated an early (within few days) favourable effect of medically supervised fasting (for 7-20 days) on depressive symptoms, and an improvement in mood, alertness, pain and a sense of tranquility $(16,17)$. However, the results of such experimental fasting can not be extrapolated to Islamic intermittent fasting during Ramadan because the duration of each fasting episode of experimental fasting is usually more prolonged than the duration of fasting during Ramadan. Moreover, Ramadan fasting has unique characteristics. During every day of the month of Ramadan, Muslims abstain from food, drink and smoking between dawn and sunset, enacting a sudden shift in the circadian pattern of food intake (18). Ramadan occurs in the ninth month of the lunar calendar, lasting between 29 and 30 days. The lunar calendar does not correspond to the Gregorian calendar therefore, Ramadan's occurrence can vary from one season to another. Daily routines are markedly altered during Ramadan. They also vary depending on geographic situation, socioeconomic level, and specific customs of each country (19).

The effect of Ramadan on health has been studied extensively, for example, in relation to lipid profile, diabetes mellitus, kidney disease, body composition, dietary intake, metabolic markers, biochemical and hematological parameters and other physiological parameters. Although various studies aimed to explore different aspects of Ramadan fasting, the effects of fasting during the month of Ramadan have not been studied adequately in relation to psychiatric disorders. On extensive literature search, we could only find a few studies examining the relationship between fasting and mood changes. The objective of this study was to explore the psychological effects that occur during the Ramadan month, especially effects on depression, anxiety, and stress. In the present study, we aimed to investigate the spiritual status of healthy volunteer people and to compare mood state of them before and after month of Ramadan.

\section{Methods}

In this cross-sectional type study, the universe of the research is composed of healthy volunteer people who registered at the Kayapinar Peyas family health centre in Diyarbakır and declared they planned to fast at the month of Ramadan in 2017. After the literature search, a questionnaire form was prepared. The form included a demographic questionnaire eliciting information regarding age, gender, marital status and educational level and Turkish version of the depression anxiety and stress scale (DASS-42). This questionnaire contained 42 questions, of which there were 14 questions related to stress, 14 questions about anxiety, and 14 ones assessing depression. Each question has a four-part range in which options are graded from 0 to 3 . Based on the depression scale, those receiving between 0-9 points were considered normal, while those with 10 and more points were evaluated as depressive; those receiving 0-7 points from anxiety scale were considered normal, while those with 8 and more points were regarded as anxious; those receiving 0-14 points from stress scale were evaluated as normal, while those with 15 or more points were considered stressful. The validity and reliability of the questionnaire in Turkish have been approved by Bilgel and Bayram (20). Ethically, the participants were informed about the aims of the study and they were asked if they would like to volunteer for participation. They were also informed that they could withdraw from the study an any time and that all information would be kept strictly confidential. The online questionnaire technique was used to obtain the datavia e-mail and smart phone. The study was conducted during the summer of 2017. The survey conducted to the same healthy volunteer group one weak before Ramadan (May 22-26) and at the end of Ramadan (June 21-25). Before the Ramadan 105 volunteer people participated to the survey, but 20 of them gave up and 85 people participated at the end of Ramadan.

We know that factors such as environment, education, economy, geography, season, occupation play a significant role in the etiology of mental illnesses such as depression, anxiety and stress. Therefore, we have included people who have the same education level, who have regular economic income, live in the same geographical area especially in the same district. In addition, the criteria for participant exclusion from the study were as follows: "Have you experienced a major event such as accident-death that could seriously affect your psychology in the last year?", "Do you have any psychiatric treatment in the last 6 months?", "Do you have a chronic illness?" and "Do you have any drug use continuously?" those who answered "Yes" to the questions $(\mathrm{n}=12)$ were excluded from the evaluation. Thus, the confounding factors were intended to be minimized. The remaining 73 healthy subjects with no known health problems and who were not in the risk groups in terms of mental and physical health were included in the statistical evaluation. 


\section{Statistical analysis}

SPSS 21.0 statistical package was used in the data analysis. Data were expressed as frequency, percentage and means (SD). The reliability of the survey was tested and the Cronbach's Alpha value was calculated as 0.966. Kolmogorov Smirnov, Mc Nemar, Wilcoxon and t tests were used. The statistical analyses were considered significant if $\mathrm{p}<0.05$.

\section{Results}

In this study, 73 people were included in the evaluation. The mean (SD) age of the participants was $30.7 \pm 7.8$ (range, 19-55 years). Among the participants, $86.3 \%(n=63)$ were male and $13.7 \%(n=10)$ were female. All participants in the study are university graduates. Other sociodemographic data of participants were summarized in table 1 .

Table 1. The Socio-demographic Features of Sample

\begin{tabular}{llcc}
\hline \multirow{4}{*}{ Gender } & & $\mathbf{n}$ & $\boldsymbol{\%}$ \\
\cline { 2 - 4 } Marital status & Male & 63 & $\mathbf{8 6 . 3}$ \\
& Female & 10 & $\mathbf{1 3 . 7}$ \\
& Single & 31 & $\mathbf{4 2 . 5}$ \\
Educational status & Married & 42 & $\mathbf{5 7 . 5}$ \\
Do you smoke & University & 51 & $\mathbf{6 9 . 9}$ \\
cigarette? & Master's degree / doktorate & 22 & $\mathbf{3 0 . 1}$ \\
& No & 11 & $\mathbf{1 5 . 1}$ \\
& Yes & 62 & $\mathbf{8 4 . 9}$ \\
Job & Lawyer & 5 & $\mathbf{6 . 9}$ \\
& Health care worker & 16 & $\mathbf{2 2 . 2}$ \\
& Official & 7 & $\mathbf{9 . 7}$ \\
& Student & 12 & $\mathbf{1 6 . 7}$ \\
& Teacher & 27 & $\mathbf{3 7 . 6}$ \\
Monthly Income & Housewife & 5 & $\mathbf{6 . 9}$ \\
& Less than the minimum wage & 6 & $\mathbf{8 . 2}$ \\
& Minimum wage & 6 & $\mathbf{8 . 2}$ \\
& 2 times the minimum wage & 22 & $\mathbf{3 0 . 1}$ \\
& 3 times the minimum wage and more & 39 & $\mathbf{5 3 . 5}$ \\
\cline { 2 - 4 } & & $\mathbf{7 3}$ & $\mathbf{1 0 0 . 0}$ \\
\hline
\end{tabular}

According to the DASS score, when the pre-Ramadan scores of the sample were compared to the post-Ramadan scores; depression ( $\mathrm{p}=0.001$ ), anxiety ( $\mathrm{p}=0.01)$ and stress ( $\mathrm{p}=0.002)$ scores were found to be lower at the end of Ramadan (Table 2).

Table 2. Comparison of total depression, anxiety and stress scores before and after Ramadan

\begin{tabular}{|c|c|c|c|c|}
\hline & & $\operatorname{mean} \pm \mathbf{s d}$ & $t^{*}$ & $\mathbf{p}$ \\
\hline \multirow{2}{*}{ DEPRESSION } & Pre-Ramadan Month & $8.5 \pm 7.5$ & \multirow{2}{*}{3.370} & \multirow{2}{*}{$\mathrm{p}=0.001$} \\
\hline & Post-Ramadan Month & $6.1 \pm 6.2$ & & \\
\hline \multirow{2}{*}{ ANXIETY } & Pre-Ramadan Month & $7.2 \pm 5.6$ & \multirow{2}{*}{2.664} & \multirow{2}{*}{$\mathrm{p}=0.01$} \\
\hline & Post-Ramadan Month & $6.0 \pm 4.7$ & & \\
\hline \multirow{2}{*}{ STRESS } & Pre-Ramadan Month & $12.7 \pm 7.8$ & \multirow{2}{*}{3.297} & \multirow{2}{*}{$\mathrm{p}=0.002$} \\
\hline & Post-Ramadan Month & $10.4 \pm 7.4$ & & \\
\hline
\end{tabular}

*: Paired t test was used

When compared to the pre-Ramadan scores of sample and the post-Ramadan scores; depression, anxiety and stress prevalence were found to be lower at the end of Ramadan. Before the Ramadan the prevalence of depression was detected $37.0 \%$ and at the end of Ramadan detected $26.0 \%$ ( $p>0.05$ ). Before the Ramadan the prevalence of anxiety was detected $39.7 \%$ but at the final week of Ramadan detected 26.0\% ( $<<0.05$ ). Finally, before the Ramadan the prevalence of stress was detected 35.6\%, while the rate was $24.3 \%$ at the final week of Ramadan (p>0.05) (Table 3). 
Table 3. Comparison of depression, anxiety and stress frequency before and after Ramadan

\begin{tabular}{|c|c|c|c|c|c|c|}
\hline \multirow[b]{2}{*}{$n=73$} & \multicolumn{2}{|c|}{ DEPRESSION* } & \multicolumn{2}{|c|}{ ANXIETY* } & \multicolumn{2}{|c|}{ STRESS* } \\
\hline & $\begin{array}{c}\text { Pre- } \\
\text { Ramadan } \\
\%\end{array}$ & $\begin{array}{c}\text { Post- } \\
\text { Ramadan\% }\end{array}$ & $\begin{array}{c}\text { Pre- } \\
\text { Ramadan\% }\end{array}$ & $\begin{array}{c}\text { Post- } \\
\text { Ramadan\% }\end{array}$ & $\begin{array}{c}\text { Pre- } \\
\text { Ramadan\% }\end{array}$ & $\begin{array}{c}\text { Post- } \\
\text { Ramadan\% }\end{array}$ \\
\hline Normal & 63.0 & 74.0 & 60.3 & 74.0 & 64.4 & 75.3 \\
\hline Light & 16.4 & 17.8 & 11.0 & 5.5 & 12.3 & 16.4 \\
\hline Middle & 9.6 & 4.1 & 17.8 & 13.7 & 13.7 & 5.5 \\
\hline Forward & 8.2 & 1.4 & 5.5 & 5.5 & 9.6 & 1.4 \\
\hline Very Forward & 2.7 & 2.7 & 5.5 & 1.4 & 0.0 & 1.4 \\
\hline TOTAL & 100.0 & 100.0 & 100.0 & 100.0 & 100.0 & 100.0 \\
\hline p & \multicolumn{2}{|c|}{$p>0.05$} & \multicolumn{2}{|c|}{$\mathrm{p}<0.05$} & \multicolumn{2}{|c|}{$\mathrm{p}>0.05$} \\
\hline
\end{tabular}

*: Mc nemar test was used

Table 4. Comparing the samples with normal mood before and after Ramadan

\begin{tabular}{|c|c|c|c|c|}
\hline \multirow{3}{*}{$\begin{array}{c}\text { DEPRESSION } \\
\quad(n=46)\end{array}$} & & Mean \pm SD & $\mathbf{t}$ & $\mathbf{p}^{*}$ \\
\hline & Pre-Ramadan Month & $3.9 \pm 2.9$ & \multirow[t]{2}{*}{0.000} & \multirow[t]{2}{*}{$\mathrm{p}>0.05$} \\
\hline & Post-Ramadan Month & $3.9 \pm 3.9$ & & \\
\hline \multirow{2}{*}{$\begin{array}{c}\text { ANXIETY } \\
(\mathrm{n}=44)\end{array}$} & Pre-Ramadan Month & $3.5 \pm 2.1$ & \multirow[t]{2}{*}{0.970} & \multirow[t]{2}{*}{$\mathrm{p}>0.05$} \\
\hline & Post-Ramadan Month & $3.8 \pm 2.7$ & & \\
\hline \multirow{2}{*}{$\begin{array}{c}\text { STRESS } \\
(\mathrm{n}=47)\end{array}$} & Pre-Ramadan Month & $8.0 \pm 4.2$ & \multirow{2}{*}{0.733} & \multirow{2}{*}{$\mathrm{p}>0.05$} \\
\hline & Post-Ramadan Month & $7.6 \pm 4.5$ & & \\
\hline
\end{tabular}

\footnotetext{
*: Paired t test was used.
}

In the pre- and post-Ramadan DASS score comparison of the persons who were evaluated normally in terms of depression $(n=46)$, anxiety $(n=44)$ and stress $(\mathrm{n}=47)$ accordıng to DASS score before Ramadan, no statistically significant difference was found in depression, anxiety and stress between before the Ramadan and the end of Ramadan ( $p>0.05$ ) (Table 4).

The post-Ramadan DASS scores of the the persons who were evaluated depressive ( $n=27)$, anxious ( $n=29)$ and stressful $(n=26)$ according to preRamadan DASS score, were found to be significantly lower at the end of Ramadan $(\mathrm{p}<0.05)$ (Table 5).

Table 5. Comparison of anxious, depressive and stressful people before and after Ramadan

\begin{tabular}{clccc}
\hline & & Mean \pm SD & $\begin{array}{c}\text { Median } \\
\text { (Min- Max })\end{array}$ & p* \\
\cline { 2 - 5 } $\begin{array}{c}\text { DEPRESSION } \\
(\mathrm{n}=27)\end{array}$ & Pre-Ramadan Month & $16.4 \pm 6.3$ & $15(10-30)$ & $\mathrm{p}<0.001$ \\
& Post-Ramadan Month & $9.8 \pm 7.5$ & $10(0-30)$ & \\
$\begin{array}{c}\text { ANXIETY } \\
(\mathrm{n}=29)\end{array}$ & Pre-Ramadan Month & $12.8 \pm 4.4$ & $11(8-22)$ & \\
& Post-Ramadan Month & $9.2 \pm 5.2$ & $8(1-21)$ & $\mathrm{p}<0.001$ \\
$\begin{array}{c}\text { STRESS } \\
(\mathrm{n}=26)\end{array}$ & Pre-Ramadan Month & $21.1 \pm 5.3$ & $20(15-33)$ & \\
& Post-Ramadan Month & $15.6 \pm 7.7$ & $14(3-40)$ & $\mathrm{p}=0.001$ \\
\hline
\end{tabular}

\footnotetext{
*: Wilcoxon test used.
}

\section{Discussion}

Ramadan is a month held important by the Muslim population. Ramadan fasting is unique because of its intermittent nature and also has many spiritual benefits. It allows deep introspection and an increased awareness of one's relationship with God and others around them, a greater appreciation of blessings, and it encourages compassion, care, and charity. There are several physical benefits too. Fasting reduces low-density lipoprotein and cholesterol levels, and improves weight and glycaemic control (21). Although Ramadan fasting imposed no adverse effects on 
short-term memory and did not negatively impact the cognitive flexibility function $(13,22)$, results in another study show that the effect of fasting on cognition is heterogeneous and domain-specific (23).

To date, there are only a few studies that have examined the effects of Ramadan fasting on psychological state and mental health, especially on anxiety, depression and stress. In these investigations, there were no differences in tension, depression, anger, vigor, and confusion estimated by the profile of mood states questionnaire. Only fatigue was higher at the end of Ramadan (24). The result of a pilot study indicates that the Ramadan month may disrupt the mood state of bipolar patients. The relapses were not associated with a change of blood level of lithium. Most of the relapses were of a manic type (77.7\%) (25). On the contrary, Farooqa et al. did not find evidence of significant deterioration in mood and mental state. None of the patients relapsed requiring admission or change in treatment. They observed a significant reduction in Hamilton Depression Rating Scale scores during Ramadan compared with pre-Ramadan assessment. The scores on Young Mania Rating Scale also showed a significant decrease during Ramadan compared with pre and post-Ramadan assessments (14).

Koushali et al. investigated effect of Ramadan fasting on emotional reactions in nurses. The level of their emotional reactions was assessed by DASS questionnaire in two stages over 1-2 weeks before and after Ramadan. The findings showed that depression and stress levels were significantly reduced after in comparison with the levels before the Ramadan ( $\mathrm{p}<0.05$ ). Despite the reduction of anxiety level in fasting after Ramadan, the difference was not significant (26). In contrast, an other study's findings demonstrate that Ramadan fasting did not significantly influence mood (27).

The results of the present study reveal that according to the DASS score, depression anxiety and stress levels were significantly reduced at the end of in comparison with the levels before the Ramadan ( $\mathrm{p}<0.05$ ). Before the Ramadan; according to DASS score, the persons who were evaluated normally in terms of mood state, when the before Ramadan scores were compared to the end of Ramadan there was no statistical significant in depression, anxiety and stress between pre- and post-Ramadan. Therefore, it can be said that Ramadan fasting has not a negative effect on human psychology in healthy individuals. The persons who were evaluated depressive, anxious and stressful, when the before Ramadan scores were compared to the end of Ramadan depression, anxiety and stress scores were found to be lower at the end of Ramadan. Thus, it can be said that Ramadan has a positive effect on the psychology of individuals who are experiencing depression, anxiety and stress.

\section{Limitations}

Our study had some limitations, including a small sample size especially in women. We recommend that the study in a larger sample size, should be performed in further investigations.

\section{Conclusion}

Millions of Muslims observe fasting in a wide variety of climatic conditions every year. However, epidemiological research is sparse especially in relation to psychiatric disorders. The current study results demonstrated that fasting in the month of Ramadan has been effective in diminishing stress, anxiety, and depression levels. However, it needs to be more elaborated and confirmed through further investigations in the future.

\section{Conflict of interest: None \\ Financial disclosure: None}

\section{References}

1. Sadock BJ, Kaplan HI, Sadock VA. 10th ed. Philadelphia: Lippincott Williams and Wilkins; 2007. Kaplan and Sadock's synopsis of psychiatry: Behavioral sciences/clinical psychiatry.

2. Ellison CG, Boardman JD, Williams DR, et al. Religious involvement, stress, and mental health: Findings from the 1995 Detroit Area Study. Soc Forces 2001; 80:215-49. https://doi.org/10.1353/sof.2001.0063

3. Agardh A, Emmelin M, Muriisa R et al. Social capital and sexual behavior among Ugandan university students. Glob Health Action 2010; 3:1-13. https://doi.org/10.3402/gha.v3i0.5432

4. Myer L, Stein DJ, Grimsrud A, et al. Social determinants of psychological distress in a nationally-representative sample of South African adults. Soc Sci Med 2008; 66:1828-40. https://doi.org/10.1016/j.socscimed.2008.01.025

5. Azizi F. Islamic fasting and health. Annals of nutrition and metabolism 2010; 56(4):273-82. https://doi.org/10.1159/000295848

6. Wilson MH. The relationship between religiosity and quality of life in patients with implantable cardioverter defibrillators East Carolina University, Dissertation. 2010. http://thescholarship.ecu.edu/bitstream/handle/10342/3193/Wilson ecu 0600D 10294.pdf. Accessed: 01.01.2018.

7. Rajaei AR. Religious cognitive-emotional therapy: A new form of psychotherapy. Iran J Psychiatry 2010; 5:81-7. PMCID: PMC3430504.

8. Nursi S. The letters. The twenty ninth letter second section, which is the Second Treatise. On the Month of Ramadan. http://www.erisale.com/index.jsp?locale=tr\#content.tr.2.566 Accessed: 01.01.2018.

9. Ünalacak M, Kara IH, Baltaci D, et al. Effects of Ramadan fasting on biochemical and hematological parameters and cytokines in healthy and obese individuals. Metabolic syndrome and related disorders 2011; 9(2):157-61. https://doi.org/10.1089/met.2010.0084 
10. Farooq A, Herrera CP, Almudahka F, et al. A prospective study of the physiological and neurobehavioral effects of Ramadan fasting in preteen and teenage boys. Journal of the Academy of Nutrition and Dietetics 2015; 115(6):88997. https://doi.org/10.1016/j.jand.2015.02.012

11. Sadiya A, Ahmed S, Siddieg HH, et al. Effect of Ramadan fasting on metabolic markers, body composition, and dietary intake in Emiratis of Ajman (UAE) with metabolic syndrome. Diabetes, Metabolic Syndrome and Obesity: Targets and Therapy 2011; 4:40916. doi: https://dx.doi.org/10.2147\%2FDMSO.S24221

12. Bakhit AA, Kurdi AM, Wadera JJ, et al. Effects of Ramadan fasting on moderate to severe chronic kidney disease: A prospective observational study. Saudi Medical Journal 2017; 38(1):48-52. doi: https://dx.doi.org/10.15537\%2Fsmj.2017.1.17566

13. Najafabadi MG, Nikoukar LR, Memari A et al. Does Ramadan fasting adversely affect cognitive function in young females? Scientifica 2015; http://dx.doi.org/10.1155/2015/432428

14. Farooqa S, Nazara Z, Akhtera J, et al. Effect of fasting during Ramadan on serum lithium level and mental state in bipolar affective disorder. International Clinical Psychopharmacology 2010; 25:323-27. doi: https://doi.org/10.1097/YIC.0b013e32833d18b2.

15. Lauche R, Fathi I, Saddat C, at al. The effects of Ramadan fasting on physical and mental health in healthy adult Muslims-Study protocol for a randomised controlled trial. Advances in Integrative Medicine 2016; 3(1):26-30. doi: https://doi.org/10.1016/j.aimed.2016.07.001

16. Fond G, Macgregor A, Leboye M, et al. Fasting in mood disorders: neurobiology and effectiveness. A review of the literature. Psychiatry research 2013; 209(3):253-8. doi: https://doi.org/10.1016/j.psychres.2012.12.018

17. Michalsen A. Prolonged fasting as a method of mood enhancement in chronic pain syndromes: a review of clinical evidence and mechanisms. Curr. Pain Headache Rep 2010; 14:80-7. doi: https://doi.org/10.1007/s11916-010-0104-z

18. BaHammam AS, Almushailhi K, Pandi-Perumal SR, et al. Intermittent fasting during Ramadan: does it affect sleep?. Journal of sleep research 2014; 23(1):35-43. doi: https://doi.org/10.1111/jsr.12076

19. Kadri N, Tilane A, El Batal M, et al. Irritability during the month of Ramadan. Psychosomatic Medicine 2000; 62(2):280-5.

20. Bilgel N, Bayram N. Turkish version of the depression anxiety stress scale (DASS-42): Psychometric properties. Archives of Neuropsychiatry 2010; 47:118-26. doi: https://doi.org/10.4274/npa.5344

21. Kul S, Savas E, Ozturk ZA, et al. Does Ramadan fasting alter body weight and blood lipids and fasting blood glucose in a healthy population? A meta-analysis. J Relig Health 2014; 53(3):929-42. doi: https://doi.org/10.1007/s10943-013-9687-0

22. Chamari K, Briki W, Farooq A, et al. Impact of Ramadan intermittent fasting on cognitive function in trained cyclists: a pilot study. Biology of sport 2016; 33(1):49. doi: https://doi.org/10.5604/20831862.1185888

23. Tian HH, Aziz AR, Png W, et al. Effects of fasting during Ramadan month on cognitive function in Muslim athletes. Asian Journal of Sports Medicine 2011; 2(3):145-53. PMCID: PMC3289210

24. Chtourou H, Hammouda O, Souissi H, et al. The effect of Ramadan fasting on physical performances, mood state and perceived exertion in young footballers. Asian Journal of Sports Medicine 2011; 2(3):177. PMCID: PMC3289213

25. Kadri N, Mouchtaq N, Hakkou F, et al. Relapses in bipolar patients: changes in social rhythm?. The The International Journal of Neuropsychopharmacology 2000; 3(1):45-9. https://doi.org/10.1017/S1461145799001704

26. Koushali AN, Hajiamini Z, Ebadi A, et al. Effect of Ramadan fasting on emotional reactions in nurses. Iranian journal of nursing and midwifery research 2013; 18(3):232. PMCID: PMC3748544

27. Nugraha B, Ghashang SK, Hamdan I, et al. Effect of Ramadan fasting on fatigue, mood, sleepiness, and health-related quality of life of healthy young men in summer time in Germany: A prospective controlled study. Appetite 2017; 111:38-45. https://doi.org/10.1016/j.appet.2016.12.030 